\title{
DIETARY INTAKE OF SULPHITES BY CHILDREN IN THE SLOVAK REPUBLIC
}

\author{
Terézia Šinková, Katarína Janeková \\ Food Research Institute, Bratislava, Slovak Republic
}

\section{SUMMARY}

The mean dietary intake of sulphites by Slovak children aged 7 to 10 years was estimated. Calculations were based on a food model of a specific boarding-school in January, May, July and October while respecting the scientifically recommended dietary allowances. It was assumed that sulphites were used in the widest possible range of foods and at maximum permitted levels. Due to this fact and since sulphites are partially lost during food processing and storage, the results are over-estimated. However the mean daily exposure of consumers with the lowest $(21 \mathrm{~kg})$ and the mean ( $26.5 \mathrm{~kg}$ ) body weight to sulphites ranged from 44 to $55 \%$ and from 36 to $43 \%$ of the acceptable daily intake value (ADI) respectively. Due to availability of various foods the dietary models were not affected seasonally and thus no differences among intakes of sulphites in individual months were obvious. The results indicated that the above mentioned group of children is sufficiently protected from the hazard of sulphites in food.

Key words: sulphites, legislation, dietary intake, ADI value, dietary exposure

Address for correspondence: T. Šinková, Food Research Institute, 82475 Bratislava 26, Priemyselná 4, PO Box 25, Slovak Republic, E-mail: terezia.sinkova@vup.sk

\section{INTRODUCTION}

Sulphur dioxide and sulphites represent a group of food additives highly effective against bacteria, molds, and yeasts. In addition they are used in a variety of foods to prevent enzymatic and/or non-enzymatic browning and act as antioxidants, reducing and bleaching agents. The $\mathrm{SO}_{3}^{2-}$ free radical reacts with a whole range of food compounds (aldehydes, ketones, reducing sugars, proteins and amino acids). As a result various compounds (both, desirable and undesirable) can be created with stability depending especially on types of basic compounds and acidity of media. Sulphites can react with some vitamins $\left(B_{1}, B_{2}, C, K\right)$ and cause their destructions $(1,2)$.

Chemical reactivity of sulphites raises questions regarding their safety. Results of some toxicology studies indicate that some individuals are sensible to sulphites depending on form of their binding in food and thus identical concentration of sulphites can result in various consequences. The negative manifestation is partially due to their destructive effect on thiamine. Based on extensive studies the Joint FAO/WHO Expert Committee on Food Additives (JECFA) defined the no-observed effect level value (NOEL) and allocated the ADI value $0-0.7$ to sulfur dioxide and some of its equivalents. Consequently other compounds (sulphites) were added to this group $(3,4,5,6,7,8)$. Legislation of the Slovak Republic (SR) enables to use eight food additives of this group: $\mathrm{SO}_{2}$ (E 220), $\mathrm{Na}_{2} \mathrm{SO}_{3}$ (E 221), $\mathrm{NaHSO}_{3}$ (E 222), $\mathrm{NaS}_{2} \mathrm{O}_{5}$ (E 223), $\mathrm{KS}_{2} \mathrm{O}_{5}$ (E 224), $\mathrm{CaSO}_{3}$ (E 226), $\mathrm{CaH}_{2} \mathrm{~S}_{2} \mathrm{O}_{6}$ (E 227) and $\mathrm{KHSO}_{3}(\mathrm{E} 228)$. They are applied mainly when preserving fruits and vegetables and in wine production process - these additives are indicated as sulphites and expressed in concentration of sul- fur dioxide regardless their sources and roles in food. Residual concentrations in a whole range of food products are defined as the entire sulphite content from any sources (9).

Risk analysis by means of dietary additives intake monitoring is the inevitable provision for health protection of inhabitants. If the additive is approved for use, its presence in the diet and the range of actual intake by the consumer should be monitored in order to confirm its safety in use. Exposure to the food additive can be estimated as its mean consumption in defined period of time. Consumption that falls on one day and kilogram of body weight is calculated and compared with the ADI value $(10,11)$. There is a whole range of dietary assessment methodologies and the evaluation of risk associated with food additive intakes is dependent on an estimation of the long-term variations in food consumption by individuals (12). Every type of survey generates data with particular variability and uncertainty (13).

Dietary intakes of sulphites have been estimated in many countries using various methods. The intake data based on nutrition models ranged from 0.03 up to $30 \mathrm{mg} / \mathrm{kg}$ bw. The JECFA concluded that exposure of population to sulphites assessed from maximum permitted limits of some countries is below the ADI value. However a higher exposure is likely if their residual concentrations approach the limits. Consequently, depending on nutrition habits of some population groups the higher intake of sulphites may be assumed $(8,14)$.

Harmonisation of legislation represents a base of exposure monitoring within the European Community. The European Union approved a tiered approach of evaluation the dietary intake of food additives. Under this method sulfur dioxide was moved to the tier 3 belonging thus to the compounds which should be 
watched carefully. Exposure of population to sulphites as reported from Denmark, Spain, France, Italy, the Netherlands, UK and Norway was estimated to range from 20 to $266 \%$ of ADI. High intake values were calculated on assumption that sulphites were present in a broad variety of food and at maximum permitted concentrations. Intake of sulphites by children observed in France and UK was significantly higher, from 83 to $1227 \%$ of ADI (14). French results indicate that the highest intake (exceeding the ADI values) is evident at western coast of the country marked with diet rich in dried fish, dried fruits and wine (15).

Estimation of exposure to food additives belongs to the aims of the National Nutrition Restoring Programme of Slovak Population. It represents a tool for identification a problem that can come either from legislation inadequacy or from wrong dietary habits (10). The mean dietary intake of sulphites by Slovak inhabitants exceeding the ADI value was estimated from both - consumption statistics data and scientifically recommended food allowances $(16,17)$. To give precision to the results this study was aimed at estimation of intake by children that may be sensible to sulphites more than adult population.

Table 1 Exposure of consumers aged 7 to 10 years to dietary sulphites

\begin{tabular}{|c|c|c|c|c|}
\hline Month & Week & $\begin{array}{c}\text { Total SO } \\
\text { intake } \\
\text { (mg/per- } \\
\text { son/week) }\end{array}$ & $\begin{array}{c}\text { Daily exposure } \\
\text { of a mean } \\
\text { consumer at } \\
21 \mathrm{~kg} \mathrm{bw} \\
\text { (\% ADI) }\end{array}$ & $\begin{array}{c}\text { Daily exposure } \\
\text { of a mean } \\
\text { consumer } \\
\text { at } 26.5 \mathrm{~kg} \\
\text { bw (\% ADI) }\end{array}$ \\
\hline \multirow{5}{*}{ January } & 1 & 31.2 & 30.28 & 24.00 \\
\hline & 2 & 95.3 & 92.57 & 73.28 \\
\hline & 3 & 28.2 & 27.28 & 21.71 \\
\hline & 4 & 32.4 & 31.42 & 24.85 \\
\hline & mean & 38.7 & 45.38 & 35.96 \\
\hline \multirow{5}{*}{ May } & 1 & 36.9 & 35.85 & 28.28 \\
\hline & 2 & 36.4 & 35.28 & 28.00 \\
\hline & 3 & 69.6 & 65.57 & 53.57 \\
\hline & 4 & 57.0 & 55.28 & 43.85 \\
\hline & mean & 50.0 & 47.99 & 38.42 \\
\hline \multirow{5}{*}{ July } & 1 & 62.2 & 60.42 & 47.85 \\
\hline & 2 & 54.9 & 53.28 & 42.14 \\
\hline & 3 & 49.9 & 48.42 & 38.28 \\
\hline & 4 & 75.0 & 72.85 & 57.71 \\
\hline & mean & 48.0 & 58.74 & 46.49 \\
\hline \multirow{5}{*}{ October } & 1 & 76.7 & 74.42 & 59.00 \\
\hline & 2 & 47.7 & 46.28 & 36.71 \\
\hline & 3 & 54.9 & 53.28 & 42.14 \\
\hline & 4 & 45.9 & 44.57 & 35.28 \\
\hline & mean & 56.3 & 54.76 & 43.28 \\
\hline
\end{tabular}

\section{METHODS}

Dietary intake of sulphites by a vulnerable consumer group was evaluated in accordance with the scientifically based risk assessment policy and the EU approach while considering its tendentious overestimate. It was assumed that the products can contain the maximum amounts of individual additives as defined in the Food Codex of the SR (9).

The food chemical exposure is generally expressed as milligrams per kilogram of body weight per day ( $\mathrm{mg} / \mathrm{kg}$ bw/day) while the chemical can potentially be present in a whole range of food items.

Actual dietary exposure of children aged 7-10 years to sulphites at a specific boarding-school was estimated. The school provides regularly 5 meals a day. Composition of the menus is derived from the Alimenta software of the Food Data Bank (located at the Food Research Institute, Bratislava) that enables to consider given criteria. Recommendations of the SR Ministry of Health while respecting scientifically recommended allowances of individual nutrients and foodstuffs for the mentioned age group of Slovak consumers (18) are usually taken into account resulting in dietary diversity. In addition, the cuisine of the boarding school approaches the traditional nutritional habits of Slovak consumers marked with prevalence of cooked dishes prepared from basic raw materials.

The quality of results may be affected with the assessed period of exposure time. In order to achieve information on eventual variations, the model menus covering the months in different seasons (January, May, July and October) were considered on the assumption that sulphites are used in the widest possible range of foods and at maximum permitted levels.

The total content of sulphites in one portion of meal was calculated taking into account the intakes in individual weeks and months.

In order to pursue and to compare intake of sulphites with the ADI value, the checked up mean body weight of the indicated group of consumers $(26.5 \mathrm{~kg})$ and the lowest one $(21 \mathrm{~kg})$ was taken into account (19). The mean exposure was calculated and expressed as mg fallen upon $1 \mathrm{~kg}$ of body weight of a person per day in individual weeks and months. The intake of sulphites was compared with the ADI $0-0.7 \mathrm{mg} / \mathrm{kg}$ bw/day.

Due to assumed over-estimation as mentioned above the exposure results lower than the ADI value were considered safe.

\section{RESULTS}

Table 1 shows extend of exposures of the studied consumer group to sulphites as influenced by specific dietary model. The weekly intake ranged from 28 to $95 \mathrm{mg}$ sulphites per person representing the daily exposure of consumers with the lowest $(21 \mathrm{~kg})$ and the mean $(26.5 \mathrm{~kg})$ body weight 27 to $93 \%$ ADI and 22 to $73 \%$ ADI respectively. The mean daily exposure to sulphites calculated in individual months ranged from 6 to $8 \mathrm{mg}$ per person while representing 44 to $55 \%$ and 36 to $43 \%$ ADI.

Individual sources of sulphites in the dietary model are reviewed in Table 2. The amounts of sulphites are given as the theoretic concentration (considering the maximum permitted concentrations in food) in a daily portion of the dietary model covering 4 months. The share of individual food products on the total intake of sulphites is shown. It is evident that industrial fruit and vegetable products are the main donors. 
Table 2 Mean intake of sulphites from dietary model potential sources in 4 months (January, May, July, October)

\begin{tabular}{|l|c|c|c|c|}
\hline Source & $\begin{array}{c}\text { Maximum } \\
\text { limit in } \\
\text { food } \\
\text { (mg/kg) }\end{array}$ & $\begin{array}{c}\text { SO intake } \\
\text { (mg/per- } \\
\text { son/4 } \\
\text { months) }\end{array}$ & $\begin{array}{c}\text { SO intake } \\
\text { (mg/per- } \\
\text { son } \\
\text { /day) }\end{array}$ & $\begin{array}{c}\text { Share on } \\
\text { total } \\
\text { exposure } \\
\text { (\%) }\end{array}$ \\
\hline Breakfast sausages & 450 & 104.10 & 1.28 & 16.8 \\
\hline Canned vegetables & 100 & 203.03 & 1.82 & 23.8 \\
\hline Dried raisins & 2000 & 29.82 & 0.27 & 3.5 \\
\hline Fruit preserves & 100 & 126.50 & 1.30 & 17.0 \\
\hline Jams & 100 & 38.49 & 0.39 & 5.2 \\
\hline Lemon juice & 350 & 156.74 & 1.40 & 18.4 \\
\hline Nuts & 500 & 8.83 & 0.08 & 1.1 \\
\hline Sugar & 10 & 27.59 & 0.25 & 3.3 \\
\hline Mustard & 250 & 61.62 & 0.55 & 7.2 \\
\hline Vinegar & 170 & 31.11 & 0.28 & 3.7 \\
\hline
\end{tabular}

\section{DISCUSSION}

Sulfur dioxide and sulphites are approved food additives that assist to ensure quality and safety of some food products, on the other hand in sensitive consumers namely asthmatics they may induce some health problems (1). The unique character of sulphites causes their partial losses during food processing and storage resulting in lower residual levels. For example it is known that due to rehydration and cooking of dried vegetable is their content when consumed much lower than the added one (7).

The exposure monitoring can serve as a tool of discovering the defects that may be rooted either in legislative imperfections or in nutrition. Considering potential sources of sulphites it is obvious that their intake depends considerably on dietary habits of individuals.

There are more than 4,000 results of the long-term monitoring of sulphites saved in the Database of Food Contaminants as run under the Slovak Ministry of Agriculture and covering the official inspection within the time period 1999-2003. It should be noted that the sulphite levels in foods are much lower than the maximum limits set in the Slovak Food Codex. Since the results had not covered all related potential sources of sulphites they were not considered complete for the exposure estimation in this study. However the trend of differences from defined maximum limited levels should be taken into account what means that the exposure is overestimated approximately by one third.

The exposure of the given group of children to sulphites in individual weeks and months was lower than the ADI value even considering the over-estimated results. No significant changes arisen from different dietary composition in individual seasons of year could be seen. This fact may be caused with availability of various food and varied dietary models in the boarding-school respecting the rules of rational nutrition.

It is evident that fruit and vegetable products represent the main sources of sulphites. They are present in various preserved products such as marmalades and juices as well in dried fruits and other products. Respective shares of fruit products, vegetable products and lemon juice in the daily intake were $1.7,1.8$ and $1.4 \mathrm{mg}$ sulphites.

In contrast to statistic evidence of fairly high consumption of processed meat products that reflect traditional dietary habits of Slovak inhabitants (17) these types of products were involved in the mentioned dietary model very rarely. Only breakfast sausages were included from time to time. On the other hand, the maximum acceptable limit of sulphites in breakfast sausages is set fairly high $(450 \mathrm{mg} / \mathrm{kg})$ and consequently, despite that entire amount of sausages consumed by children was not more than $320 \mathrm{~g}$ during the observation time period, their share in total sulphite intake represented about $17 \%$.

A special mention should be made about potatoes as the noted compounds of our nutrition. Their consumption was about $12,630 \mathrm{~g}$ by a person in the related 4 months. It is known that our households and boarding establishments use raw potatoes predominantly. There is a maximum limit of sulphites $50 \mathrm{mg} / \mathrm{kg}$ in ready-to-cooked potato products. The limit is rather low on the other hand it could contribute to increased exposure in case of their regular usage instead of raw materials by additional $5 \mathrm{mg} /$ person/day. Consequently the potato semi products would become the main source of sulphites sharing more than $40 \%$ of the total exposure which would represent in consumers of the mean and of the lowest body weight 66 to $77 \%$ ADI and 83 to $97 \%$ ADI respectively.

Contrary to the results of our previous study based on consumption statistics this study respects the real diet of the given consumer group and the results are not biased with statistical data on consumption of some food items that are usually not consumed by children such as wine or beer (14). An extensive campaign aimed at rational nutrition has been run in the Slovak Republic for many years. It can be presumed that the recommended dietary manners come into practice step by step and most of children are nourished by the diet that does not differ too much from the one of the studied group. The mentioned dietary model is noted with prevalence of fresh fruits and vegetables while the industrial products representing the main sources of sulphites are used only complementarily. Even when the doses of sulphites from individual sources are accumulated their concentrations are still sufficiently low not to endanger health of the consumers.

As a matter of fact it can be stated that nutrition of children aged 7 to 10 years in accordance with scientific recommendations results in a low exposure to sulphites regardless the season of the year. Current national legislation plus fair dietary practices marked with consumption of a broad variety of food are the sufficient guarantees of the long-term exposure lower than the ADI value.

\section{Acknowledgement}

The authors wish to thank the schoolmasters to the Boarding School for Disabled Children in Bratislava, Mokrohájska cesta, for their willingness to offer the base for this study.

\section{REFERENCES}

1. Concon JM. Food Toxicology: Part B. Contaminants and Additives. New York: Marcel Dekker, Inc.; 1988.

2. Davidson PM, Juneja VK, Branen JK. Food Additives. In: Branen AL, Davidson PM, Salminen S, Thorngate JH, editors. Antimicrobial Agents. New York: Marcel Dekker, Inc.; 2002. p.563-620. 
3. Joint FAO/WHO Expert Committee on Food Additives. Evaluation of the toxicity of a number of antimicrobials and antioxidants. Geneva: WHO; 1962. WHO Technical Report Series No. 228

4. Joint FAO/WHO Expert Committee on Food Additives. Specifications for the identity and purity of food additives and their toxicological evaluation: Food colours and some antimicrobials and antioxidants. Geneva: WHO; 1965. WHO Technical Report Series No. 309

5. Joint FAO/WHO Expert Committee on Food Additives. Specifications for the identity and purity of food additives and their toxicological evaluation: some antimicrobials, antioxidants, emulsifiers, stabilizers, flour-treatment agents, acids, and bases. Geneva: WHO; 1966. WHO Technical Report Series No. 339.

6. Joint FAO/WHO Expert Committee on Food Additives. Toxicological evaluation of certain food additives with a review of general principles and of specifications. Geneva: WHO; 1974. WHO Technical Report Series No. 539.

7. Joint FAO/WHO Expert Committee on Food Additives. Evaluation of certain food additives and contaminants. Geneva: WHO; 1987. WHO Technical Report Series No. 751.

8. Joint FAO/WHO Expert Committee on Food Additives. Evaluation of certain food additives. Geneva: WHO; 2000. WHO Technical Report Series No. 891.

9. Decree of the SR Ministry of Agriculture and the SR Ministry of Health from 15th March 2004 No. 608/5/2004-100 issuing the chapter of the Food Codex of the Slovak Republic regulating food additives. Vestník Ministerstva pôdohospodárstva SR a Ministerstva zdravotníctva SR. 2004 Apr 1; 36(10-II/A): p.231-469. (In Slovak.)
10. Šinková T, Janeková K, Kováč M. Methods of food additive intake assessment Bulletin potravinárskeho výskumu. 2003;42(1-2): p.1-7. (In Slovak.)

11. Douglas JS, Trennant DR. Estimation of dietary intake of food chemicals. In: Trennant DR, editor. Food Chemical Risk Analysis. London: Blackie Academic \& Hall; 1997. p.193-239.

12. Salminen S, Tahvonen R. Food Additive Intake Assessment. In: Branen LA, Davidson PM, Salminen S, Thorngate JH, editors. Food Additives. New York: Macel Dekker Inc.; 2002. p.11-25.

13. FAO/WHO. Food Safety Risk Analysis. Part II. Case Studies. Rome; 2005.

14. Report from the Commission on Dietary Food Additive Intake in the European Union. Brussels; 2002.

15. Verger PH, Chambolle M, Babayous P, Le Breton S, Volatier JL. Estimation of the distribution of the maximum theoretical intake for ten additives in France. Food additives and contaminants. 1998;15(7):759-66.

16. Šinková T, Janeková K, Kováč M, Kováčiková E. Dietary intake estimate of sulphites in the Slovak Republic. Bulletin potravinárskeho výskumu. 2004;43(1-2):67-77. (In Slovak.)

17. Food Consumption in the Slovak Republic. Bratislava: Statistic Bureau of the Slovak Republic; 2003. (In Slovak.)

18. Kajaba I, Šimončič R, Ginter E, Ondrejka J, Kalač J, Trusková I, Bzdúch V. Recommended dietary allowances for the inhabitants of the Slovak Republic. Bulletin of the SR Ministry of Health. 1997;45 (Part 7-8). (In Slovak.)

19. Vademecum Medici. Martin: Osveta; 1985. (In Slovak.)

Received July 25, 2005 Received in revised form and accepted November 14, 2005 